\title{
PENGARCAAN DI CANDI BUMIAYU SEBAGAI SUMBER PEMBELAJARAN IPS TERPADU (SEJARAH)
}

\author{
Oleh: Susilawati ${ }^{\star}$, Sukardi $^{* *}$ \\ *Mahasiswa Program Studi Pendidikan Sejarah FKIP Universitas PGRI Palembang \\ ${ }^{*}$ Dosen Program Studi Pendidikan Sejarah FKIP Universitas PGRI Palembang
}

\begin{abstract}
ABSTRAK
Percandian Bumiayu di Desa Tanah Abang kabupaten Penukal Abab Lematang llir berasal dari masa Sriwijaya. Candi Bumiayu identik dengan arca dan relief yang kaya dengan nilai sejarah dan budaya. Arca di candi Bumiayu dapat dimanfaatkan sebagai sumber pembelajaran sejarah. Rumusan masalah penelitian ini: Apakah pengarcaan di percandian Bumiayu dapat dijadikan sebagai sumber pembelajaran IPS terpadu (sejarah) Tujuan penelitian ini: (1) Untuk mengetahui lokasi serta lingkungan alam yang terdapat di Candi Bumiayu agar dapat dijadikan sebagai sumber pembelajaran IPS terpadu (sejarah). (2) Untuk mengetahui analisis Pengarcaan dari Candi 1 Bumiayu agar dapat dijadikan sebagai sumber pembelajaran IPS terpadu (sejarah).(3) Untuk mengetahui analisis Pengarcaan dari Candi 3 Bumiayu sebagai sumber pembelajaran IPS terpadu (sejarah). Metode yang digunakan dalam penelitian deskriptif kualitatif. Teknik pengumpulan data yaitu: dokumentasi, observasi, wawancara. Teknik analisis data yang digunakan adalah teknik analisis model analisis interaktif. Kesimpulan penelitian: Pengarcaan di candi Bumiayu yang terdapat di candi 1 dan candi 3 Bumiayu bercorak Hindu. Pengarcaan di candi Bumiayu dapat menambah pengetahuan siswa tentang sejarah lokal di Sumatera Selatan.
\end{abstract}

Kata Kunci: Arca, Candi Bumiayu, Sumber Pembelajaran, IPS terpadu (Sejarah)

\section{A. PENDAHULUAN}

Dalam kehidupan manusia membutuhkan berbagai kebutuhan hidup yang sangat berpengaruh untuk masa depan. Kebutuhan hidup manusia berupa kebutuhan jasmani dan kebutuhan rohani, dalam pemenuhan kebutuhan jasmani manusia pasti membutuhkan makan, sandang dan papan untuk hidup. Sedangkan dalam kebutuhan rohani manusia membutuhkan agama dengan salah satu sarana untuk beribadah adalah arca (Hadimuljono,1982:82).

Arca merupakan sebuah patung yang dibuat dengan tujuan utama sebagai media keagamaan, yaitu sarana dalam memuja Tuhan atau dewa-dewinya. Dalam pembuatan arca tidak semudah seperti membuat patung pada umumnya, patung hanya merupakan hasil seni yang dimaksudkan sebagai sebuah keindahan, biasanya arca menyerupai bentuk binatang atau manusia. Arca-arca yang menggambarkan bentuk binatang seperti gajah, harimau dan monyet (Poesponegoro, 1993:216).

Keberadaan situs candi Bumiayu pertama kali dilaporkan oleh Tombrink dari negara Belanda pada tahun 1864. Selanjutnya dalam laporan Knapp dari negara Belanda pada tahun 1904 mengadakan perjalanan melalui sungai Lematang ia sampai pada sebuah gundukan (tumulus) yang tingginya setinggi 1,75 meter berstruktur bata. Menurut penduduk situs ini merupakan peninggalan kerajaan Kadebong Undang yang wilayahnya mencakup Modong dan Babat (Munandar,2007:5).

Di situs Babat terdapat sesosok arca Brahma dan di situs Modong terdapat lingga. Kawasan situs Bumiayu, situs Modong dan Babat menempati lembah sungai Lematang. Secara administratif kawasan situs Bumiayu terletak di desa Bumiayu, kecamatan Tanah Abang, 
kabupaten Pali, provinsi Sumatera Selatan. Sedangkan situs Modong berada di bagian hilirnya berjarak sekitar $17 \mathrm{~km}$. Situs Modong dan Babat kini hanya menyisakan pecahan-pecahan bata kuno dan lokasi di sekitar situs Modong telah menjadi lahan pemakaman penduduk. Sebagian besar sisa bangunan bata telah hilang karena pengikisan tebing sungai

Hubungan dagang dengan India telah menyebabkan terjadinya perubahanperubahan dalam bentuk tata negara di sebagian daerah Indonesia. Selain itu, telah terjadi perubahan dalam tata dan susunan masyarakatnya sebagai akibat penyebaran agama Budha dan Hindu (Poesponegoro,1993:26). Proses masuknya pengaruh India ke suatu daerah umumnya dikenal dengan istilah Hindunisasi. Namun sebenarnya tidak hanya pengaruh Hindu yang masuk. Dalam proses itu, berkembang pula pengaruh agama Budha dan bentukbentuk kepercayaan lainnya (Oktorino,2009:22).

Pulau Sumatera mendapat pengaruh Hindu diperkirakan abad ke-6 Masehi, yaitu situs Kota Kapur, pulau Bangka. Agama ini selanjutnya berkembang ke Palembang yang kemudian menjadi ibu kota kerajaan Sriwijaya. Ketika Kerajaan Sriwijaya berjaya penganut Hindu lebih banyak bermukim di daerah pedalaman. Pada masa Sriwijaya, agama dan kesenian berkembang pesat, kesenian yang berkembang khususnya seni bangunan dan seni arca. Pada masa itu banyak didirikan bangunan candi dan arca-arca yang ditujukan untuk kegiatan keagamaan. Berkembangnya kesenian tidak terlepas dari dukungan penguasa dan peranan sungai Musi yang menghubungkan daerah pedalaman dengan daerah pesisir Timur Sumatera (Munandar,2007:59).

Kawasan situs candi mengarah pada hubungan antara Kerajaan Sriwijaya di Sumatera dan kerajaan-kerajaan di
Jawa. Pada abad IX Masehi terjadi peperangan antara raja Balaputra dengan iparnya, Rakai Pikatan. Balaputra berhasil dikalahkan kemudian melarikan diri ke Swarnadwipa dan menjadi raja di Sriwijaya. Jadi arca-arca yang bergaya seni Jawa Tengah atau bergaya Sailendra dibawa oleh keluarga Sailendra (Balaputra) yang menyingkir ke Sumatera pada pertengahan abad ke-9 Masehi.

Salah satu bukti kejayaan agama Hindu di Sumatera adalah situs Bumiayu, tepatnya berada di desa Bumiayu, kecamatan Tanah Abang, kabupaten Pali, provinsi Sumatera Selatan. Letak geografisnya di 40-80 Lintang Selatan dan 1040-1060 Bujur Timur. Situs Bumiayu mendapat pengaruh agama Hindu sekitar abad ke-9 Masehi, hal ini tak lepas dari kegiatan perdagangan yang berlangsung pada waktu itu, lagi pula lokasi situs strategis, yaitu di jalur perdagangan internasional yang dahulu banyak didatangi kapal-kapal dagang baik lokal maupun dari luar. Di dalam percandian Bumiayu terdapat beberapa kompleks percandian, di setiap kompleks candi ditemukan arca-arca yang penggambarannya memiliki keunikan dibanding dengan arca-arca dari daerah lain. Pada penggambaran arca-arca dari percandian Bumiayu banyak dipengaruhi kesenian Hindu (Munandar,2007:59).

Arca adalah suatu benda yang dibuat oleh manusia dengan sengaja untuk memenuhi kebutuhan tertentu. Nilai seni yang terapat pada arca itu menyangkut unsur-unsur gaya yang penggarapannya menentukan indah buruknya arca sebagai ekspresi dorongan keindahan pada manusia. Gaya adalah suatu kelompok yang ditandai oleh gugusan ciri-ciri yang sama menunjukkan suatu kegiatan. Kesatuan gaya dalam suatu kelompok dapat disebabkan karena kelompok arca tersebut mewakili masa, wilayah geografi, lingkungan penduduk 
agama dan hasil karya dari seniman yang sama (Marhaeni,2000:10).

Sejarah memberikan pengetahuan yang lebih luas terhadap siswa khususnya tentang peninggalan-peninggalan lokal yang berada di Sumatera Selatan. Sehingga siswa dapat memahami letak kesalahan pengalaman pada masa itu agar tidak diulanginya lagi dan terjadi untuk kedua kalinya. Selain itu siswa dapat terinspirasi dalam mengembangkan sesuatu yang sudah ada dari pengalaman belajar sejarah dan siswa juga dapat terhibur dengan mendatangi situs sejarah untuk melihat koleksi-koleksi benda sejarah (Soekmono, 1981:99).

Pulau Sumatera memiliki posisi yang sangat strategis dan sangat berpengaruh dalam membentuk tempat persebaran situs-situs permukiman. Telah memungkinkan daerah-daerah pesisir di wilayah ini menjadi tempat persinggahan para pedagang dari Barat ke Timur serta sebaliknya. Akibat keterbatasan informasi tertulis dari dalam negeri, pengetahuan kita tentang Sumatera hingga pertengahan abad VII sejauh ini hanya dapat diketahui melalui berbagai artefak atau unsur-unsur sosial budaya lainnya yang tersebar secara terbatas di beberapa daerah (Poesponegoro,1993:65).

Mengingat pentingnya pengetahuan tentang peninggalan-peninggalan kebudayaan agama Hindu salah satunya adalah arca. Maka arca sebagai sumber pembelajaran yang lebih mendalam kepada siswa mengenai pengarcaan di candi Bumiayu, agar siswa mempunyai wawasan yang lebih luas tentang arca yang berada di Sumatera Selatan.

\section{B. METODE PENELITIAN}

Metode deskriptif kualitatif dapat digunakan untuk menggambarkan keadaan atau suatu kejadian, dalam hal ini penulis ingin menggambarkan segala sesuatu yang berhubungan dengan judul penelitian, yaitu pengarcaan di candi
Bumiayu sebagai sumber pembelajaran (sejarah) IPS terpadu kelas VII SMP Sriguna Palembang.

\section{Teknik Pengumpulan Data}

Dalam melakukan penelitian ini, peneliti menggunakan teknik observasi, wawancara dan dokumentasi.

\section{Validitas Data}

Validitas data menurut Sutopo (2006:229), guna menjamin dan mengembangkan validitas data yang akan digunakan dalam penelitian ini, teknik pengembangan validitas data yang biasa digunakan dalam penelitian kualitatif yaitu teknik trianggulasi. Trianggulasi merupakan cara yang paling umum digunakan bagi peningkatan validitas data dalam penelitian kualitatif. Dalam kaitannya dengan hal ini Patton (1984) menyatakan bahwa ada empat macam teknik trianggulasi, yaitu (1) trianggulasi data yaitu peneliti dalam mengumpulkan data wajib menggunakan beragam sumber berbeda-beda yang disajikan. (2) triangulasi metode, yaitu hasil peneliti mengumpulkan data sejenis tapi menggunakan metode yang berbeda. (3) trianggulasi peneliti, yaitu hasil penelitian dapat diuji validitasnya oleh beberapa peneliti lain. (4) trianggulasi teori, yaitu peneliti menggunakan perspektif lebih dari satu teori dalam membahas permasalahan yang dikaji (Arikunto, 2013:91).

\section{Teknik Analisis Data}

Teknik analisis data menurut Sutopo (2006:23), proses analisis dilakukan sejak awal bersamaan dengan proses pengumpulan data dalam bentuk refleksi. Peneliti menggunakan model analisis interaktif. Dalam model ini terdapat beberapa komponen analisisnya yaitu:

Pengumpulan Data: Pengumpulan data merupakan proses yang berlangsung sepanjang penelitian, dengan menggunakan seperangkat instrument 
yang telah disiapkan, guna memperoleh informasi data melalui observasi, wawancara dan mencatat dokumen.

Reduksi Data: Reduksi data menunjukkan proses menyeleksi, memfokuskan, menyederhanakan, mengabstraksikan dan mentransformasikan data mentah yang muncul dalam penulisan dari catatan lapangan.

Display Data: Display Data adalah usaha merangkai informasi yang terorganisir dalam upaya menggambarkan kesimpulan dan pengambilan tindakan.

Verifikasi dan Penarikan Kesimpulan: Verifikasi dan penarikan kesimpulan merupakan aktifitas analisis, dimana pada pengumpulan data, seorang analisis bisa memutuskan apakah sesuatu bermakna atau tidak mempunyai keteraturan, pola, penjelasan, kemungkinan komposisi. Model analisis interaktif dapat digambar dengan skema sebagai berikut:

\section{HASIL DAN PEMBAHASAN}

Berdasarkan pada sudut kelerangan, morfologi situs Bumiayu dibedakan menjadi 2 satuan, yaitu satuan morfologi dataran dan satuan morfologi bergelombang lemah. Satuan morfologi dataran mempunyai sudut kelerangan lebih kecil 50 menempati bagian tengah dari situs, khususnya arah Timur Barat. Sedangkan satuan morfologi bergelombang lemah mempunyai sudut kelerangan antara 5-150 merupakan bukitbukit kecil yang menempati sebagian areal di sebelah Utara Tenggara dan Barat Daya dan situs Bumiayu.

Bila ditinjau dari pola pengeringan permukaan situs Bumiayu dan sekitarnya mempunyai jenis pola aliran dendritik dengan sungai utama adalah sungai Lematang yang terdapat di sebelah Timur situs yang mempunyai arah aliran dari Barat Daya ke Timur Laut. Anak sungai atau cabang sungai utama yaitu sungai Lematang yang mengalir di sekitar situs, antara lain sungai Tebat Siku di sebelah
Barat, sungai Tebat Jambu di sebelah Utara, sungai Piabung di sebelah Timur, sungai Lebak Tolib dan beberapa sungai yang tidak mempunyai nama. Sungai yang berada di sebelah Utara, Timur, Selatan dan Barat merupakan sungai yang mengelilingi situs dan sungai tersebut saling berhubungan, yang kemudian menyatu dan mengalir kearah sungai Lematang (Tim Studi,1996:4).

Secara genetik sungai Lematang merupakan sungai utama mempunyai arah aliran yang sejajar dengan kemiringan lapisan batuan dimasukkan dalam jenis sungai konsekwen. Dilihat dari debet air yang mengalir secara menerus untuk setiap tahunnya, sungai Lematang termasuk sungai permanen. Jika didasarkan jenis erosi sungai, dimana erosi horizontal terlihat lebih dominan dari erosi vertikal, tetapi erosi vertikal masih terjadi, maka sungai Lematang tersebut mempunyai stadium dewasa. Untuk litologinya, secara regional situs Bumiayu dan sekitarnya dapat dikorelasikan bagian atas dari formasi Muara Enim yang mengandung Fosil Haplohragnoides. Sp dan Giungelocina. $S p$ yang berumur Pliosen bawah yang diendapkan di lingkungan laut dangkal sampai lingkungan transisi (data wawancara lapangan dengan Heri Setianto).

Secara lokal, susunan litologi situs Bumiayu yang diambil dari hasil pengamatan-pengamatan yang dilakukan di tebing sungai Lematang sebelah Timur dari candi 1 , terdiri dari batu lempung tufaan berwarna kuning kecoklatan, struktur masif dengan komposisi mineral lempung. Dalam batu lempeng tufaan ini terdapat sisipan batu pasir tufaan dan batubara muda. Sisipan batu pasir tufaan tersebut mempunyai warna abu-abu kecoklatan dengan struktur masif dengan komposisi fragmen batuan beku, kwarsa, mika, dan lain sebagainya. Sedang sisipan yang lain yaitu batubara muda dengan warna hitam, kilap kaca, struktur 
mengerpih serta komposisi adalah karbon (Tim Studi,1996:5).

Jadi keadaan fisik lingkungan situs candi Bumiayu itu dibedakan atas 2 satuan, yaitu satuan morfologi dataran dan satuan morfologi bergelombang yang sekitarnya di kelilingi oleh sungai Lematang. Sungai Lematang merupakan sungai utama, jika dilihat dari debet air yang mengalir secara terus-menerus setiap tahunnya sungai Lematang termasuk sungai permanen dari anak sungai seperti sungai Tebat Jambu, sungai Piabung dan sungai Tebat Siku. Secara lokal, susunan situs Bumiayu terdiri dari batu lempeng tufaan berwarna kuning kecoklatan terdapat sisipan batu pasir tufaan dan batu bara muda.

\section{Iklim}

Secara geografis situs Bumiayu terletak pada dataran rendah dengan ketinggian $25 \mathrm{~m}$ di atas permukaan laut dan berbatasan dengan sungai Lematang. Sebagaimana daerah Sumatera lainnya, kawasan situs Bumiayu yang secara administratif berada di wilayah kabupaten Penukal Abab Lematang llir termasuk daerah yang beriklim tropis lembab, dengan curah hujan yang cukup tinggi. Hasil perekaman data yang dilakukan antara tahun 1987 sampai dengan 1991 menunjukkan curah hujan yang berkisar 875-2442 mm. Musim penghujan berlangsung selama 6 bulan yaitu dari bulan Oktober sampai dengan Maret. Sedangkan musim kemarau berlangsung mulai bulan April sampai dengan September. Rata-rata lama penyinaran bulanan yang terjadi pada tahun 19921996 berkisar antara 4,4-6,8 jam, dengan rata-rata lama penyinaran tertinggi terjadi pada bulan Juni dan Agustus. Sedangkan rata-rata lama penyinaran terendah terjadi pada bulan Januari dengan lama penyinaran 4,4 jam (Tim Studi,1996:6).

Suhu udara rata-rata bulanan berkisar diantara 26,1-270, C suhu udara rata-rata bulanan terendah terjadi pada bulan Februari tahun 1994 (25,90 C) dan tertinggi terjadi pada bulan September $1994(28,00 \mathrm{C})$. Kelembapan udara makro berkisar diantara 81,3\%-89,5\% dengan kelembapan rata-rata tertinggi sebesar sebesar $92,5 \%$ terjadi pada bulan Januari 1993 dan terendah sebesar 75,4\% yang terjadi pada bulan September 1994. Dari lingkungan mikro, berdasarkan atas hasil perekaman data selama studi menunjukkan kondisi kelembapan udara rata-rata sebesar $82,1 \%$ dengan kisaran diantara 80,6\%-85,4\%. Sedangkan suhu rata-rata sebesar $28,5^{\circ} \mathrm{C}$ dengan kisaran 28,00C (Tim Studi,1996:7). Jadi keadaan iklim situs candi Bumiayu tepatnya di desa Bumiayu kecamatan Tanah Abang kabupaten Penukal Abab Lematang Ilir beriklim tropis lembab, dengan curah hujan yang cukup tinggi, karena musim penghujan berlangsung selama 6 bulan yaitu bulan Oktober sampai dengan Maret sedangkan musim kemarau berlangsung mulai bulan April sampai dengan September.

\section{Lingkungan Sosial}

Luas desa Bumiayu yang merupakan tempat di mana situs Bumiayu berada kurang lebih sebesar $3.750 \mathrm{Ha}$, dengan jumlah penduduk sebanyak 541 jiwa, terdiri dari 276 jiwa $(51,02 \%)$ laki-laki dan 265 jiwa (48,98\%) wanita, dan jumlah kepala keluarga sebanyak 109 KK, yang tersebar dalam 2 RT dan 1 RW dengan Islam sebagai agama yang dipeluk $(100 \%)$.

Tingkat pendidikan penduduk di desa Bumiayu cukup baik, karena dari 541 jiwa terdapat 200 jiwa (39\%) yang berpendidikan SD 170 jiwa (32\%) berpendidikan SMP 100 jiwa (20\%) berpendidikan SMA dan 71 jiwa $(9 \%)$ Perguruan Tinggi. Sebagian besar penduduk memenuhi kebutuhan hidupnya dengan bertani $(90 \%)$, dengan tanaman utama karet yang merupakan produk 
pertanian utama di desa Bumiayu. Selain karet tanaman yang dibudidayakan adalah pohon kelapa. Sarana desa yang ada berupa: kantor desa, sarana peribadatan 1 masjid dan pasar karet (Tim Studi,1996:8).

Jadi keadaan lingkungan sosial di candi Bumiayu tepatnya di desa Bumiayu kecamatan Tanah Abang kabupaten Penukal Abab Lematang llir memiliki jumlah penduduk 541 jiwa. Penduduk sekitar sebagian besar memeluk agama Islam karena di sekitar desa Bumiayu terdapat tempat peribadatan berupa masjid. Penduduk sekitar untuk memenuhi kebutuhan hidupnya dengan cara bertani, kebun karet, selain bertani mereka juga membudidayakan pohon kelapa.

\section{Analisis Arca Dari Arca Siwa Mahadewa Analisis Ikonografi}

Arca Siwa ditemukan dalam beberapa bagian terpisah yang kemudian berhasil direkonstruksi. Arca ini ditemukan sudah dalam keadaan retak dan pecah pada bagian kepala atau wajah, sandaran atas hilang, tangan kiri dan kanan belakang pecah, dada sebagian pecah dan lengan bawah kiri patah. Arca digambarkan dalam sikap duduk bersila diatas padmasana. Kedua telapak tangan diatas pangkuan, yang sebagian sudah pecah sehingga tidak diketahui lagi benda yang menjadi laksananya. Sandaran ini polos tanpa hiasan. Sirascakra dipahat polos, berbentuk bulat telur sampai di belakang bahu. Asananya berupa padmasana ganda berbentuk segi empat polos di bagian bawah, sementara lapik bagian atas berhias pola segi enam. Mahkota yang dikenakan berbentuk jatamakuta berhias pola lengkungan dengan untaian manik-manik di dalamnya (Siregar,2005:7).

\section{Analisis Ikonoplastik}

Arca Siwa Mahadewa ini memakai mahkota berbentuk jatamakuta berhias pola lengkungan dengan untaian manik- manik di dalamnya. Jamang sudah dalam keadaan pecah. Kalung yang dipahatkan di bagian leher arca bersusun 2, berupa untaian manik-manik dan jumbai. Hiasan telinga pecah. Tangannya mengenakan dua gelang lengan berupa untaian manikmanik berhias simbar dengan pola sulur, sedangkan gelang tangan pecah. Gelang kaki berwujud untaian manik-manik. Arca Siwa ini tidak mempunyai ikat pinggang atau uncal yang biasanya menghiasai bagian pinggul arca. Sampur yang dikenakan hanya tampak pada bagian melingkar di paha dan simpul di kanan-kiri pinggul, ujung sampur mengarah ke atas (di atas simpul). Kain yang melekat di badan tipis, panjang sampai mata kaki dan berhias pola bunga. Selain hiasan-hiasan tersebut di belakang telinga arca terdapat untaian manik-manik menjuntai ke bahu. Menilik gaya pemahatan dan ciri-cirinya arca ini lebih mendekati gaya seni pahat pada periode Jawa Timur dan diperkirakan berasal dari abad ke-12 Masehi (Siregar,2005:7).

\section{Analisis Ikonometri}

Ukuran Arca Siwa Mahadewa memiliki Tinggi keseluruhan arca $62 \mathrm{~cm}$ padmasana, tinggi Arca antara $51 \mathrm{~cm}$, lebar $36 \mathrm{~cm}$, tebal $24 \mathrm{~cm}$, dan tebal sandaran $5 \mathrm{~cm}$ (Catatan observasi lapangan 11 Maret 2016).

\section{Analisis Ikonologi}

Siwa merupakan salah satu dari tiga dewa utama (Trimurti) dalam agama Hindu. Dalam agama Hindu, dewa Siwa Mahadewa adalah dewa Pelebur, bertugas melebur segala sesuatu yang sudah usang dan tidak layak berada di dunia fana lagi sehingga harus dikembalikan pada asalnya.

\section{Analisis Teknologi}

Arca Siwa Mahadewa ini terbuat dari batu putih (limestone), bahan yang digunakan berpartikel halus dan suhu 
pembakaran cukup. Proses pemberian hiasan pada arca Siwa Mahadewa ini menggunakan teknik tekan, gores, congkel dan tempel. Proses ini dikerjakan sebelum bahan dibakar. Pada saat bahan masih lunak dilakukan pembentukan dengan teknik tekan sehingga membentuk lekukan-lekukan postur tubuh. Teknik gores dilakukan untuk membentuk mata, telinga, hidung, mulut, rambut dan anggota-anggota badan lainnya, yaitu goresan-goresan yang melengkung dan vertikal, khususnya pada rambut (Munandar,2007:70).

Arca Siwa Mahadewa ditemukan di candi 1 Bumiayu dengan keadaan beberapa bagian terpisah, arca ini ditemukan dalam keadaan retak dan pecah pada bagian kepala atau wajah, sandaran atas hilang, tangan kiri dan kanan belakang pecah, dada sebagian pecah dan lengan bawah kiri patah.

\section{Arca Tokoh 1}

\section{Analisis lkonografi}

Arca ini keadaannya relatif utuh, tetapi pada bagian muka atas dan sandaran sebelah kiri sebagain pecah. Arca diwujudkan dalam sikap duduk di atas padmasana ganda berbentuk segi empat dengan ujung membulat. Bentuk permukaan atas asana berhias pola geometris (segi empat dengan bulatan di tengah). Arca ini digambarkan mempunyai dua tangan. Sikap kedua tangan berada di atas pangkuan, telapak tangan kiri di bawah telapak tangan kanan dan di atas telapak tangan kanan terdapat bunga padma mekar. Pada bagian sisi sandaran arca agak mengecil ke bawah, puncak membulat, sekeliling tepi berhias lidah api. Sirascakra berbentuk polos, lonjong sampai di belakang bahu (Siregar,2005:8).

\section{Analisis Ikonoplastik}

Mahkota yang dikenakan jatamakuta (mahkota yang terbuat dari pilinan rambut) meninggi, berhias simbar dan pola sulur. Hiasan lainnya ialah jamang berbentuk pita lebar berhias deretan manik-manik dihiasi lima simbar dengan pola sulur. Di samping itu juga terdapat dua kalung berhias pola sulur. Kalung yang kecil kecuali berhias pola sulur juga berhias deretan manik-manik. Hiasan telinga berwujud ratna kundala dengan pola sulur. Gelang tangan berupa pita dengan deretan manik-manik berhias simbar dengan pola sulur. Ikat pinggang yang dikenakan berupa deretan manikmanik yang bagian depannya terdapat semacam gesper berhias pola sulur. Memiliki 2 gelang kaki polos, demikian juga dengan gelang tangan (Siregar,2005:8).

\section{Analisis Ikonometri}

Arca ini berukuran tinggi keseluruhannya $62 \mathrm{~cm}$, tinggi arca $50 \mathrm{~cm}$, lebar $36 \mathrm{~cm}$ dan tebal $4,5 \mathrm{~cm}$. Berdasarkan gaya seninya arca ini berasal dari sekitar abad ke-11-12 Masehi (Catatan observasi lapangan 11 Maret 2016).

\section{Analisis Ikonologi}

Arca Tokoh 1 merupakan arca perwujudan dewa pariwara (pendamping), jadi arca tokoh 1 ini pendamping Arca Siwa.

\section{Analisis Teknologi}

Arca tokoh 1 dibuat dari batu tufa (limestone). Bahan yang digunakan berpartikel halus dan suhu pembakaran cukup. Proses pemberian hiasan pada arca tokoh 1 ini menggunakan teknik tekan, gores, congkel dan tempel. Proses ini dikerjakan sebelum bahan dibakar. Pada saat bahan masih lunak dilakukan pembentukan dengan teknik tekan sehingga membentuk lekukan-lekukan postur tubuh. Teknik gores dilakukan untuk membentuk mata, telinga, hidung, mulut, rambut dan anggota-anggota badan lainnya, yaitu goresan-goresan yang 
melengkung dan vertikal, khususnya pada rambut (Siregar,2005:20).

Jadi Arca Tokoh 1 ditemukan di

candi 1 Bumiayu dalam keadaan utuh, arca diwujudkan dalam sikap duduk di padmasana ganda berbentuk segi empat dengan ujung membulat, bentuk permukaan atas asana berhias pola geometris (segi empat dengan bulatan di tengah). Arca ini berukuran tinggi keseluruhannya $62 \mathrm{~cm}$, tinggi arca $50 \mathrm{~cm}$, lebar $36 \mathrm{~cm}$ dan tebal $4,5 \mathrm{~cm}$. Berdasarkan gaya seninya arca ini berasal dari sekitar abad ke-11-12 Masehi.

\section{Arca Tokoh 2 \\ Analisis Ikonografi}

Arca digambarkan berbadan gemuk, terutama di bagian perut Agastya atau Ganesya dari Jawa Timur. Berdasarkan langgamnya arca ini diperkirakan berasal dari kurun antara abad ke-11 dan 12 Masehi. Arca perwujudan ini ditemukan di sebelah Timur bangunan candi Bumiayu 1 dalam keadaan retak pada bagian dada dan sandaran atas. Penggambaran arca ini dalam sikap duduk padmasana di atas asana yang berupa lapik polos setengah bulat. Mempunyai tangan dua yang terletak di atas pangkuan, telapak kiri di bawah telapak tangan, yang di atasnya terdapat bunga mekar. Sandaran tepi berjenjang, bagian bawah lebar, kemudian mengecil berbentuk lonjong, polos. Sirascakra digambarkan polos berbentuk bulat telur sampai ke belakang bahu. Pada kedua bahu terdapat rambut ikal menjurai (Siregar,2005:9).

\section{Analisis Ikonoplastik}

Hiasan yang dikenakan terdiri dari mahkota berupa jatamakuta berhias lengkung semacam jala jamang berbentuk pita lebar polos dan berhias 3 simbar dan memakai sumping. Kalung yang terdapat arca ini berjumlah dua yang berhias pola sulur tetapi dalam keadaan aus. Hiasan telinga berbentuk bulatan dan ujungnya berhias jumbai. Hiasan lain adalah gelang tangan berupa pita dengan deretan manikmanik berhias simbar dengan pola sulur. Ikat pinggang yang dikenakan berbentuk pita berhias, tetapi aus berlekuk-lekuk. Gelang berupa untaian manik-manik bersusun dua, sedangkan gelang kaki ada dua polos. Arca ini tidak memakai uncal, tetapi memakai sampur yang tidak jelas, karena hanya tampak bagian ujungnya yang menjurai di asana dan bagian yang menempel di paha, berhias geometris tetapi agak aus. Memakai kain yang panjangnya sampai betis dan berhias pola bunga, tetapi sudah aus (Munandar,2007:63).

\section{Analisis Ikonometri}

Ukuran arca tokoh 2 memiliki tinggi keseluruhan $42 \mathrm{~cm}$, lebar keseluruhan, 33 $\mathrm{cm}$, tebal keseluruhan $10 \mathrm{~cm}$ dan garis tengah keseluruhan 16,5 cm (Catatan observasi lapangan 11 Maret 2016).

\section{Analisis Ikonologi}

arca tokoh 2 merupakan arca perwujudan dewa pariwara (pendamping), jadi arca tokoh 2 ini pendamping arca Siwa.

\section{Analisis Teknologi}

Arca tokoh 2 ini terbuat dari batu putih (limestone). Bahan yang digunakan berpartikel halus dan suhu pembakaran cukup. Proses pemberian hiasan pada arca tokoh 2 ini menggunakan teknik tekan, gores, congkel dan tempel. Proses ini dikerjakan sebelum bahan dibakar. Pada saat bahan masih lunak dilakukan pembentukan dengan teknik tekan sehingga membentuk lekukan-lekukan postur tubuh (Munandar,2007:70). Jadi arca tokoh 2 ditemukan dari candi 1 Bumiayu yang digambarkan berbadan gemuk, dalam sikap duduk diatas asana berupa lapik polos setengah bulat dengan sandaran tepi berjenjang, bagian bawah 
lebar, kemudian mengecil berbentuk lonjong polos.

\section{Arca Agastya}

\section{Analisis Ikonografi}

Agastya digambarkan berdiri, bertangan dua dan berjanggut panjang. Agastya ini termasuk dalam kelompok dewa pariwara (pendamping) bersama Ganesya dan Durga Mahisasuramardhini. Dalam konstelasi arca pada candi Hindu, arca Agastya diletakkan pada salah satu sisi ruang atau relung candi utama (induk), yaitu pada sisi Selatan. Adapun ciri-ciri Agastya dari Bumiayu ini antara lain: membawa kamandalu (kendi), aksamala (tasbih), berperut buncit (gendut) dan trisula dipahatkan menempel pada sandaran arca sebelah kanan. Arca Agastya dari candi Bumiayu 1, ditemukan secara terpisah dalam dua bagian. Sebagian sandarannya telah patah. keadaan arca relatif utuh, tetapi sebagain kepala pecah, sandaran kiri pecah dan mengalami keretakan pada beberapa bagian. Penggambaran arca yakni dalam posisi berdiri diatas padmasana ganda berbentuk segi empat membulat, bagian atas berhias pola geometris segi enam yang menggambarkan bentuk biji teratai. Asana ini terdiri dari dua bagian, satu bagian menjadi satu dengan tokoh arca, sedangkan bagian lainnya berupa asana yang jika digabungkan membentuk rongga. Arca dipahatkan bertangan dua, tangan kanan berada di depan perut memegang aksamala dan tangan kiri lurus ke bawah memegang kendi (kamandalu). Sandaran arca merupakan bentuk sisi sejajar, polos yang pecah pada bagian puncaknya. Sirascakra tidak ditemukan pada arca Agastya ini (Munandar,2007:64).

\section{Analisis Ikonoplastik}

Pada Arca Agastya ini mahkota dan jamang yang terdapat pada arca pecah sehingga tidak teridentifikasi. Meskipun demikian terlihat adanya sumping di bagian telinganya. Di kedua bahu terdapat rambut ikal menjurai. Hiasan lain yang dikenakan adalah kalung berhias pola bunga dan sulur, sedangkan hiasan telinga membentuk bulatan dengan jumbai. Gelang lengan berupa pita polos, berhias simbar dengan sulur. Ikat pinggang lebar dengan hiasan yang tidak jelas, sedangkan ikat pinggul berhias semacam gesper tetapi sudah aus. Gelang tangan ada dua, polos, sementara gelang kaki, polos. Arca digambarkan memakai uncal yang pada bagian depannya berhias gesper tetapi aus, ujungnya menguntai sampai ke bawah lutut. Mengenakan sampur di paha dengan simpul berbentuk kipas di kiri-kanan badan, ujungnya menjurai berlipat-lipat, ujung simpul pendek hanya sampai lutut. Kain yang dikenakan tipis, berhias pola bunga, panjangnya sampai di atas pergelangan kaki tetapai bagian bawahnya berlekuk, wiron lebih pendek. Ciri fisik menampilkan keistimewaan karena arca ini digambarkan dalam postur perut yang tidak terlalu buncit, bahkan cenderung kecil (Siregar,2005:10).

\section{Analisis Ikonometri}

Ukuran arca, tinggi keseluruhan 69 $\mathrm{cm}$, lebar $29 \mathrm{~cm}$, tinggi lapik $14 \mathrm{~cm}$ dan tebal sandaran 3,5 cm (Catatan observasi lapangan 11 Maret 2016).

\section{Analisis Ikonologi}

Dalam mitologi Hindu, Agastya dianggap sebagai pendeta yang menyebarkan agama Hindu di India Selatan, karena besar jasanya dalam menyebarkan agama maka ia dianggap sebagai salah satu aspek dari dewa Siwa mahayogi. Dalam pengarcaannya, Agastya digambarkan berdiri, bertangan dua dan berjanggut panjang. Agastya ini termasuk dalam kelompok dewa pariwara (pendamping) bersama Ganesya dan Durga Mahisasuramardhini. Dalam konstelasi arca pada candi Hindu, arca 
Agastya diletakkan pada salah satu sisi ruang atau relung candi utama (induk), yaitu pada sisi Selatan.

\section{Analisis Teknologi}

Arca yang dibuat dari batu putih (limestone), bahan yang digunakan berpartikel halus dan suhu pembakaran cukup. Proses pemberian hiasan pada Agastya ini menggunakan teknik tekan, gores, congkel dan tempel. Proses ini dikerjakan sebelum bahan dibakar. Pada saat bahan masih lunak dilakukan pembentukan dengan teknik tekan sehingga membentuk lekukan-lekukan postur tubuh. Teknik gores dilakukan untuk membentuk mata, telinga, hidung, mulut, rambut dan anggota-anggota badan lainnya, yaitu goresan-goresan yang melengkung dan vertikal, khususnya pada rambut (Munandar,2007:70).

Arca Agastya ditemukan dari Candi 1 Bumiayu dengan keadaan secara terpisah dalam dua bagian, sebagian sandarannya telah patah, keadaan arca relatif utuh, tetapi sebagian kepala pecah, sandaran kiri pecah dan mengalami keretakan pada beberapa bagian. Dalam pengarcaannya, Agastya digambarkan berdiri, bertangan dua dan berjanggut panjang. Agastya ini termasuk dalam kelompok dewa pariwara (pendamping) bersama Ganesya dan Durga Mahisasuramardhini. Dalam konstelasi arca pada candi Hindu, arca Agastya diletakkan pada salah satu sisi ruang atau relung candi utama (induk), yaitu pada sisi Selatan.

\section{Arca Stambha}

\section{Analisis Ikonografi}

Arca terdiri dari bawah ke atas: gajah, ghana (raksasa berbadan kerdil) dan singa yang memiliki rasa kebersamaan tanpa ada permusuhan diantaranya. Pola gajah dan singa ini merupakan pola yang populer di Indonesia dan India Timur antara abad 10-12 Masehi. Keadaannya sudah retak pada bagian bawah, yaitu singa dan kepala raksasa. Sikap arca ialah gajah dalam posisi mendekam, raksasa naik gajah dengan kedua kainya menjuntai di kirikanan badan gajah. Sikap tangan raksasa masing-masing memegang kaki singa. Singa menduduki badan raksasa, kedua kaki depan diangkat ke atas (Siregar,2005:11).

\section{Analisis Ikonoplastik}

Pada belalai gajah terdapat setangkai bunga dan daun-daunan dan mempunyai dua gading (Munandar, 2007:65).

\section{Analisis Ikonometri}

Secara keseluruhan arca ini berukuran tinggi $55 \mathrm{~cm}$. Lebar $18 \mathrm{~cm}$ dan tebal $17,5 \mathrm{~cm}$ (Catatan observasi lapangan 11 Maret 2016).

\section{Analisis Ikonologi}

Dalam sistem percandian yang dikenal di India biasanya terdapat bangunan menara di setiap sudut dekat pagar. Di atas menara-menara inilah biasanya ditempatkan suatu arca (biasanya beruapa binatang singa atau gajah) stambha sebagai hiasan puncaknya. Dengan analogi ini kemungkinan arca stambha ini juga berasal dari suatu menara yang mungkin didirikan di sekitar candi Bumiayu 1 tidak menutup kemungkinan bahwa disinilah lokasi semula arca stambha tersebut.

\section{Analisis Teknologi}

Arca Stambha terbuat dari batu andesit (Munandar, 2007:65). Jadi Arca Stambha ini ditemukan di candi 1 Bumiayu yang terdiri dari (bawah ke atas) gajah, makhluk ghana (penghuni sorga yang digambarkan seperti kanak-kanak) dan singa. Keadaannya retak pada bagian bawah, pada fitur singa kepala raksasa. Pada belalai gajah terdapat setangkai bunga dan daun-daunan dan mempunyai 
dua gading. Secara keseluruhan arca ini berukuran tinggi $55 \mathrm{~cm}$. Lebar $18 \mathrm{~cm}$ dan tebal $17,5 \mathrm{~cm}$. Kemungkinan arca stambha ini juga berasal dari suatu menara yang mungkin didirikan di sekitar candi Bumiayu 1 tidak menutup kemungkinan bahwa disinilah lokasi semula arca stambha tersebut.

\section{Arca Nandi \\ Analisis lkonografi}

Nandi adalah nama vahana (kendaraan) dewa Siwa yang berwujud binatang lembu. Arca ini ditemukan di candi Bumiayu 1. Bentuk keseluruhan dan detail hiasannya masih utuh. Posisi arca mendekam dengan kedua kaki berlipat di atas lapik berbentuk segi empat (Munandar, 2007:65).

\section{Analisis Ikonoplastik}

Arca ini memilik hiasan berupa kalung dengan bandul genta-genta kecil. Selain itu memakai hiasan kepala, yaitu diantara kedua matanya berbentuk simbar dengan motif pola sulur. Pada bagian moncongnya terdapat untaian manikmanik, mempunyai fungsi sebagai pengikatnya (Siregar,2005:11).

\section{Analisis Ikonometri}

Arca ini berukuran panjang $85 \mathrm{~cm}$ dan tinggi $35 \mathrm{~cm}$ sedangkan ukuran lapik arca panjangnya $70 \mathrm{~cm}$, lebar $37 \mathrm{~cm}$ dan tebal $4,5 \mathrm{~cm}$ (Catatan observasi lapangan 2016).

\section{Analisis Ikonologi}

Arca Nandi adalah nama vahana (kendaraan) dewa Siwa yang berwujud binatang lembu jantan.

\section{Analisis Teknologi}

Arca yang dibuat dari batu putih (limestone). Bahan yang digunakan berpartikel halus dan suhu pembakaran cukup. Proses pemberian hiasan pada arca Nandi ini menggunakan teknik tekan, gores, congkel dan tempel. Proses ini dikerjakan sebelum bahan dibakar. Pada saat bahan masih lunak dilakukan pembentukan dengan teknik tekan sehingga membentuk lekukan-lekukan postur tubuh. Teknik gores dilakukan untuk membentuk mata, telinga, hidung, mulut, dan anggota-anggota badan lainnya, yaitu goresan-goresan yang melengkung dan vertikal (Munandar,2007:70). Jadi arca Nandi ditemukan di candi 1 Bumiayu dengan keadaan keseluruhan masih utuh, arca ini merupakan kendaraan dewa Siwa Mahadewa yang berwujud binatang lembu jantan. Arca ini berukuran panjang $85 \mathrm{~cm}$ dan tinggi $35 \mathrm{~cm}$ sedangkan ukuran lapik arca panjangnya $70 \mathrm{~cm}$, lebar $37 \mathrm{~cm}$ dan tebal $4,5 \mathrm{~cm}$. Arca dibuat dari batu putih (limestone). Bahan yang digunakan berpartikel halus dan suhu pembakaran cukup. Proses pemberian hiasan pada arca Nandi ini menggunakan teknik tekan, gores, congkel dan tempel.

\section{Pembahasan}

Pengarcaan di candi Bumiayu dapat dijadikan sebagai sumber pembelajaran IPS terpadu (sejarah) kelas VII Sekolah Menengah Pertama Sriguna Palembang karena sudah memenuhi pengolahan dari kurikulum dan mengacu pada (SK) Standar Kompetensi: 5. Memahami perkembangan masyarakat sejak masa Hindu-Budha sampai masa Kolonial Eropa dan (KD) Kompetensi Dasar: 5.1 Mendeskripsikan perkembangan masyarakat kebudayaan dan pemerintahan pada masa Hindu-Budha serta peninggalan-peninggalannya. Sumber pembelajaran yang akan diterapkan sesuai dengan karakteristik mata pelajaran sejarah yang mempelajari tentang peninggalan-peninggalan sejarah Kerajaan yang bercorak Hindu dan Budha. Pada dasarnya menerapkan sumber pembelajaran lokal untuk siswa, akan lebih 
mengetahui nilai sejarah yang ada dalam daerahnya sendiri.

Pembelajaran IImu Pengetahuan Sosial di Sekolah Menengah Pertama Sriguna Palembang dari hasil observasi yang dilakukan peneliti. Pembelajaran IImu Pengetahuan Sosial di Sekolah Menengah Pertama Sriguna Palembang diajar oleh 5 orang guru yang mengajar. Mata pelajaran IPS terpadu (sejarah) di Sekolah Menengah Pertama (SMP) terdapat Standar Kompetensi (SK) dan Kompetensi Dasar (KD) yang ditetapkan oleh pemerintah. Sumber pembelajaran pengarcaan di candi Bumiayu terdapat di Standar Kompetensi: 5. Memahami perkembangan masyarakat sejak masa Hindu-Budha sampai masa Kolonial Eropa, Kompetensi Dasar: 5.1. Mendeskripsikan perkembangan masyarakat kebudayaan dan pemerintahan pada masa Hindu-Budha serta peninggalan-peninggalannya.

Di dalam sumber pembelajaran mengenai pengarcaan di candi Bumiayu untuk memahaminya seorang guru haruslah banyak membaca buku, jurnal, dan penelitian-penelitian candi Bumiayu dipugar, membaca buku tentang situs Bumiayu dapat dilakukan di perpustakaan Balai Arkeologi Palembang. Situs Bumiayu mendapat pengaruh agama Hindu sekitar abad ke-9 Masehi, hal ini tak lepas dari kegiatan perdagangan yang berlangsung pada waktu itu.

\section{SIMPULAN}

Berdasarkan hasil penelitian dan pembahasan yang sesuai dengan tujuan penelitian dapat disimpulkan sebagai berikut:

Lokasi candi Bumiayu terletak di desa Bumiayu kecamatan Tanah Abang kabupaten Penukal Abab Lematang Ilir (PALI) provinsi Sumatera Selatan. Dengan keadaan lingkungan sosial memiliki jumlah penduduk 541 jiwa. Sebagian besar penduduk memeluk agama Islam, untuk memenuhi kebutuhan hidupnya dengan cara bertani, kebun karet, selain bertani mereka juga membudidayakan pohon kelapa.

Analisis pengarcaan dari candi 1 Bumiayu dimulai dari benda-benda yang dipegang dan menjadi tanda-tanda kekhususan meliputi sikap telapak tangan sikap lengan dan benda yang dipakai berupa pakaian dan perhiasan pada arca yang terdapat di candi 1 Bumiayu antara lain: arca Siwa Mahadewa, arca tokoh 1, arca tokoh 2, arca Agastya, arca Stambha, dan arca Nandi. Analisis Pengarcaan dari candi 3 Bumiayu dilihat dari bentuk dan gaya seni arca ukuran keseluruhan pada arca nilai-nilai simbolis yang melekat pada sosok arca serta teknik pembuatan pada arca yang terdapat pada candi 3 Bumiayu antara lain: arca singa, arca pendeta, dan arca makhluk ghana.

\section{DAFTAR PUSTAKA}

Arikunto, Suharsimi. 2013. Prosedur Penelitian Suatu Pendekatan Praktik. Jakarta: PT Rineka Cipta.

Hadimuljono. 1982. Candi Jawi Peninggalan Sejarah Masa Akhir Kerajaan Singasari di Jawa Timur. Jakarta: Proyek Media Kebudayaan

Marhaeni, Tri dkk. 2000. Analisis Candi Bumiayu 3 Kabupaten Muaraenim Provinsi Sumatera Selatan. Balai Arkeologi Palembang.

Munandar, Aris Agus. 2007. Tabir Peradaban Sungai Lematang. Balai Arkeologi Palembang.

Oktorino, Nino, dkk. 2009. Muatan Lokal Ensiklopedia Sejarah dan Budaya. Jakarta: Lentera Abadi.

Poesponegoro, Djoned Marwati dan Notosusanto Nugroho. 1993. Sejarah Nasional Indonesia I. Jakarta: Balai Pustaka.

Siregar, Sondang M. 2005. Kompleks Percandian Bumiayu Kabupaten Muara Enim (Tinjauan Religi). 
Palembang: Departemen

Kebudayaan dan Pariwisata Pusat

Penelitian dan Pengembangan

Arkeologi Nasional Balai Arkeologi Palembang.

Soelaeman, Munandar. 2001. Ilmu Budaya Dasar. Bandung: PT. Refika Aditama

Sutopo. H.B. 2006. Metodologi Penelitian Kualitatif: Dasar teori dan terapannya dalam penelitian.
Surakarta: Universitas Sebelas Maret.

Tim Studi. 1996/1997. Rencana Studi Induk Pelestarian Situs Bumiayu Sumatera Selatan. Palembang: Departemen Pendidikan dan Kebudayaan Direktorat Jenderal Kebudayaan Proyek Peninggalan Sejarah dan Kepurbakalaan Pusat. 